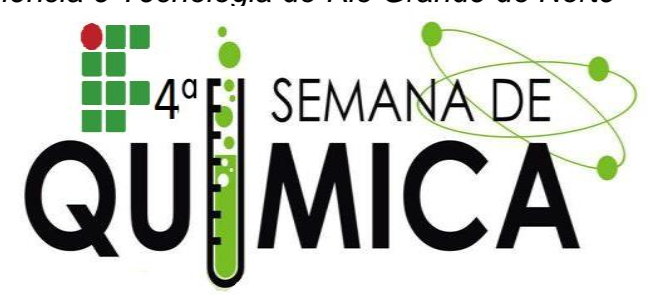

\title{
A EXPERIMENTAÇÃO A PARTIR DO ÓLEO DE FRITURAS RECICLADO
}

DIAS, E. R. (IFRN) OLIVEIRA, M.E. (IFRN) OLIVEIRA, L. L. B (IFRN) SENA, C. P. S (IFRN)

Palavras Chave: Ensino de Química, Ácidos e bases, Oficina de sabão.

\section{INTRODUÇÃO}

O experimento exerce uma função importante no conjunto educacional. Segundo Silva, Machado e Tunes (2010, p. 24 apud BRANCO, 2012), o experimento não é uma constatação do que se vê teoricamente, sendo assim, perderia o seu valor no conjunto educacional, o educando deve relacionar o que faz com o que se tem na teoria, na tentativa de explicar o que observou no experimento, proporcionando um melhor aprendizado e instigando a sua forma de observação dentro de uma perspectiva problematizadora. O presente objetivou a utilização de experimentação para associar o conteúdo de ácidos e bases contextualizado através de oficinas de produção de sabão a partir da reutilização de óleos de frituras.

O projeto teve por objetivo ativar o laboratório da instituição, promovendo aulas práticas e melhorando a compreensão e capacidade cognitiva dos alunos envolvidos.

\section{METODOLOGIA}

O desenvolvimento desse trabalho ocorreu durante a aplicação de um projeto integrador na Escola Estadual Cid Rosado, situada no município de Encanto-RN, com uma turma de 2 o ano do ensino médio. Foi realizado em momentos distintos, como mostrado no fluxograma da figura 1.

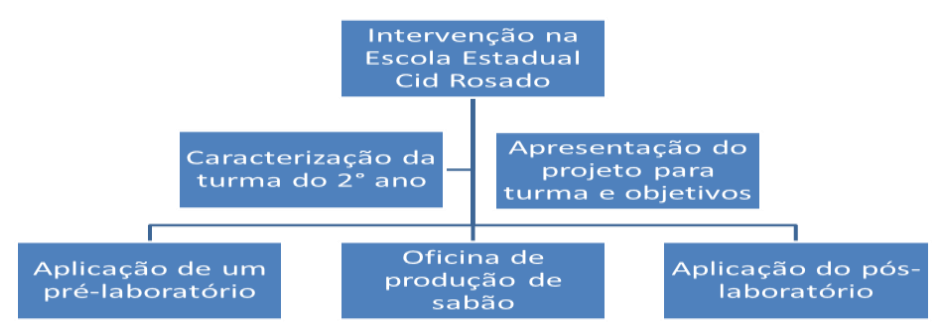

\section{RESULTADOS E DISCUSSÕES}

Em muitos momentos os alunos alegaram que "a aula era bastante interessante, diversificada e que o professor de Química deveria levá-los mais vezes lá (laboratório)". Isso é o reflexo de que a aula prática além de contribuir na aprendizagem ainda motiva os alunos. A oficina foi aplicada no laboratório da escola, após a ativação. Avaliou-se a aprendizagem dos alunos a partir de um pós-laboratório, em que os alunos através de um relatório descreveriam os processos químicos ocorridos durante a realização da oficina.

\section{CONCLUSÃO}

Com a aplicação da oficina percebeu-se o envolvimento dos alunos os quais obtiveram um bom desempenho durante a prática com os materiais totalmente recicláveis, conseguiram descrever em seus relatórios o principal objetivo da oficina, o qual seria a associação da prática com os problemas ambientais causados pelo descarte inapropriado do óleo no meio ambiente.

\section{REFERÊNCIAS}

BRANCO, Georgia Monique Rodrigues Castelo. Atividades experimentais de Química em perspectiva problematizadora: Oportunidade de promoção do diálogo entre professor e alunos. Universidade de Brasília-DF, 2012. 